\title{
Comparative Study of Methods of PHA Extraction from Bacterial Biomass
}

\author{
Evgeniy G. Kiselev ${ }^{\mathrm{a}, \mathrm{b} *}$ and Aleksey V. Demidenko ${ }^{\mathrm{a}, \mathrm{b}}$ \\ ${ }^{a}$ Institute of Biophysics SB RAS \\ 50/50 Akademgorodok, Krasnoyarsk, 660036, Russia \\ ${ }^{b}$ Siberian Federal University \\ 79 Svobodny, Krasnoyarsk, 660041, Russia
}

Received 06.03.2014, received in revised form 28.03.2014, accepted 09.06.2014

A comparative study of different methods of PHA extraction from the biomass of bacteria was carried out. It was shown that different reagents and process technologies have different effects on the extraction results - the completeness of polymer extraction and degree of its purity. Application of chloroform requires the use of large amounts of volatile and toxic reagents. When dichloromethane is used, the completeness of extraction increases, but it becomes necessary to implement procedures for separating the "extractant-precipitator" mixture. The solvent-precipitator pair (dichloromethanehexane) was selected, which does not lead to formation of an azeotropic mixture, making it possible to return up to $90 \%$ of the reactants to the process. As a result, solvent consumption went down from $73.5 \mathrm{~kg} / \mathrm{kg}$ of PHA (chloroform - hexane) to $63.7 \mathrm{~kg} / \mathrm{kg}$ of PHA (chloroform - ethanol - hexane). If ethanol is excluded, it is possible to reduce the consumption to $7.8 \mathrm{~g} / \mathrm{g}$ of PHA, but in this case additional treatment of biomass to destroy membrane complexes or sequential treatment first with alcohol and then with dichloromethane is needed. A nonchemical method using sodium dodecyl sulfate (NaDS) as a detergent allows for a more economical way to obtain high yields of polymer not contaminated with admixtures of fatty acids and suitable for technical purposes (packaging, packaging products). A combined method was developed, which considerably reduces the cost of reagents and makes it possible to obtain polymers with high purity degree and extraction completeness up to $98.5-99.0 \%$.

Keywords: polyhydroxyalkanoates, PHA, extraction, reagents.

(C) Siberian Federal University. All rights reserved

* Corresponding author E-mail address: evgeniygek@gmail.com 


\title{
Сравнительное исследование
}

\section{методов экстракции полигидроксиалканоатов \\ из биомассы бактерий}

\author{
Е.Г. Киселев ${ }^{\mathrm{a}, \boldsymbol{\sigma}}$, А.В. Демиденко ${ }^{\mathrm{a}, \boldsymbol{\sigma}}$ \\ ${ }^{a}$ Институт биофизики СО РАН \\ Россия, 660036, Красноярск, Академгородок, 50/50 \\ ${ }^{6}$ Сибирский федеральный университет \\ Россия, 660041, Красноярск, пр. Свободный, 79
}

Проведено сравнительное исследование различных методов экстракции полигидроксиалканоатов (ПГА) из биомассы бактерий. Показано, что различные реагенты и технология ведения процесса по-разному влияют на показатели - полноту извлечения полимера и степень его чистоть. Применение хлороформа делает необходимым использование большого количества летучих и токсичных реагентов. При использовании дихлорметана полнота извлечения повышается, но возникает необходимость в реализаџии процедуры разделения смеси «экстрагент-осадитель». Подобрана пара «растворитель - осадитель» (дихлорметан - гексан), которая не образует между собой азеотропную смесь, что делает возможным вернуть в процесс до $90 \%$ реагентов. В результате снизился расход растворителей с 73,5 кг/кг ПГА (хлороформ - гексан) до 63,7 кг/кг ПГА (дихлорметан - этанол - гексан). При исключении из состава этанола возможно снижение расхода до 7,8 г/2 ПГА, но в этом случае необходима дополнительная обработка биомассы с иелью разрушения мембранных комплексов или последовательная обработка сначала спиртом, а затем дихлорметаном. Безреагентный метод с применением в качестве детергента додецилсульфата натрия (ДДС-Na) позволяет более экономичным способом получать высокие выходы полимера, не загрязненного примесями жирных кислот, пригодного для технических цуелей (тара, упаковочная продукция). Разработан комбинированный метод, который значительно снижает расходы реагентов и позволяет получать полимер высокой чистоты при полноте экстракции до 98,5-99,0\%.

Ключевые слова: полигидроксиалканоаты, ПГА, экстракиия, детергентьл.

\section{Введение}

Значительную роль в общей стоимости производства полигидроксиалканоатов (ПГА) играет способ выделения полимера из клеточной биомассы. При выборе метода необходимо учитывать стоимость реагентов, количество образующихся отходов, эффективность извлечения полимера, степень его чистоты. В настоящее время используют следующие подходы для выделения полимера: экстракцию органическими растворителями; обработку биомассы растворами щелочей, кислот, детергентов, ферментами, а также их различные сочетания.

Большинство процессов выделения ПГА из клеток базируются на экстракции полимера органическими галогенсодержащими растворителями (хлороформ, дихлорметан, дихлорэтан) (Choi et al., 1999a; Choi et al., 1999b). Данный метод требует большого количества 
летучего растворителя, а это увеличивает общую стоимость производства и к тому же ведет к загрязнению окружающей среды (Choi et al., 1997). Биомассу бактерий можно предварительно обрабатывать щелочным раствором или раствором гипохлорида натрия (Hahn et al., 1994). Однако при обработке возможна деструкция эфирных связей и снижение молекулярной массы полимера (Rodrigues et al., 1995; Ramsay et al., 1994). Обработка бактериальной суспензии гипохлоридом в сочетании с поверхностно-активными веществами показала более высокую эффективность процесса экстракции с меньшим повреждением полимера. Эффективность и экономичность процесса экстракции будет в первую очередь зависеть от содержания полимера в клетках и стоимости применяемых растворителей (Page et al., 1993). В работе (Hahn et al., 1994) методом распыления хлороформа и раствора гипохлорида натрия достигнута высокая эффективность очистки с незначительной деструкцией полимера. Известен также способ, включающий температурную подготовку биомассы, ферментное разрушение клеточных стенок, выделение и промывку полимера анионными и поверхностно-активными веществами.

В связи с важным значением экстракции В общей технологической схеме получения ПГА проводятся исследования, направленные на повышение эффективности процесса за счет усовершенствования аппаратов для экстракции, применения диафильтрации (Horowitz, 2002), горячей экстракцией слаборастворяющими полимер растворителями, не содержащими галогены (Devdatt et al., 2000; Blauhut et al., 1993), использованием суперкритической флюидной экстракции жидкой двуокисью углерода (Breitenbach et al., 2000).

Второй подход получения полимера (который называют «безреагентным») заключается не в его экстракции из биомассы клеток, a в удалении загрязняющих компонентов (белков, углеводов). Как известно, полимер ассоциируется в клетках в виде гранул, однако гранулы помимо полимера содержат белкиферменты, катализирующие реакции синтеза и биораспада полимерных цепей в клетке (Steinbüchel et al., 1995a). Описано несколько методов выделения полимера, включая различные предварительные способы разрушения клеток, а именно термическую обработку биомассы с последующим перевариванием ферментами, обработку биомассы различными детергентами и растворами щелочей (Choi et al., 1999; Thakor et al., 2005). Метод выделения полимера с помощью детергентов отличается от экстракции органическими растворителями, так как разрушаются и удаляются многие клеточные компоненты и остается в виде остатка фракция полимера (Choi et al., 1999a). Например, после обработки биомассы Ralstonia eutropha растворами додецилсульфата натрия различной концентрации и нагревания суспензии до $121{ }^{\circ} \mathrm{C}$ удалось выделить гранулы полимера, содержащие только 3-4 \% примесей (Hahn et al., 1994). Анализ результатов детергентного метода получения полимера выявил недостатки этого метода, среди которых можно выделить следующие: образцы ПГА отличались недостаточной чистотой, а детергенты - высокой стоимостью. Кроме того, было показано, что этот метод требует больших количеств детергента и больших количеств воды для очистки полимера от детергента и клеточных обломков (Jian Yu, 2009). Однако в других исследованиях показано и преимущество этого метода: можно использовать сырые клетки сразу же после ферментации, для экстракционного метода воду необходимо удалять (Thakor et al., 2005). Одним из очевидных преимуществ детергентного метода является отсутствие органических растворителей. Более того, этот метод при его 
оптимизации может давать высокие выходы, он пригоден для экстракции различных типов ПГА с различным содержанием мономерных единиц различной длины C-цепей (Choi et al., 1999a.). Опробован процесс получения полимерных гранул после обработки клеток лизирующими ферментами (Jian Yu, 2009; Tamer et al., 1998). Такое извлечение особенно эффективно для выделения полимера из клеток с высоким его содержанием (Page et al., 1993).

Коллективом профессора Э. Дж. Сински и соавторами (Massachusetts Institute of Technology (MIT), США), (Yang et al., 2001; Yang et al., 2011) дана оценка возможности использования различных детергентов для выделения ПГА из клеток Ralstonia eutropha, а также рекомбинантных штаммов Escherichia coli. В этой работе показано, что в зависимости от содержания полимера в клетках исследованные детергенты позволяли получить ПГА с высоким выходом и чистотой. Детергенты на основе производных алкилбензолсульфоновой кислоты (LAS-99) обладают наиболее высокими экстрагирующими свойствами. Кроме того, LAS-99 является биодеградируемым сурфактантом и безопасен для окружающей среды. В этой связи простой метод выделения недорогими химикатами может быть наиболее эффективным и экономичным процессом выделения полимера (Yang et al., 2011).

Таким образом, известные на сегодня методы экстракции не отвечают всем необходимым требованиям (экологичность, невысокие затраты на реагенты, полнота извлечения и чистота полимера). Анализ литературы показывает необходимость оптимизации методов экстракции полимера как важного условия повышения эффективности процесса в целом и снижения стоимости полимера как конечного продукта биотехнологии. Это определило цель настощего исследования, которая на- правлена на проведение сравнительного анализа методов экстракции ПГА с применением различных реагентов.

\section{Материалы и методы}

Использованы образцы бактериальной биомассы Cupriavidus eutrophus B-10646 в виде сырой пасты (влажность 50-60 \%), полученной центрифугированием бактериальной суспензии при 6000 об/мин в течение 15 мин.

Для выбора экстрагента исследована растворимость трех образцов ПГА (гомогенного поли-3-гидроксибутирата (ПЗГБ) и двух сополимеров 3-гидроксибутирата с 3-гидроксивалератом (ПЗГБ/ПЗГВ)) в серии растворителей: хлороформе, дихлорметане, дихлорэтане, тетрахлорэтане, диоксане. Для каждой пары «полимер - растворитель» измерена оптическая прозрачность четырех растворов различной концентрации с целью выявления максимальной растворимости каждого образца в соответствующем растворителе. Полное растворение полимера считалось законченным при достижении оптической прозрачности раствора. Вязкость полимерных растворов измеряли с применением вискозиметра ВНЖ («Экохим», Россия).

В первой серии экспериментов изучено влияние объемных соотношений биомассы и экстрагента (использован хлороформ) в диапазоне от 1:5 до 1:20 на полноту экстракции полимера методом настаивания. Кроме того, варьировали длительность и кратность процесса экстракции от 2 до 24 ч и от одно- до пятикратного повторения. Наряду с этими условиями варьировали температуру экстракции в диапазоне $25-66^{\circ} \mathrm{C}$.

Во второй серии экспериментов исследовали экстракцию с помощью бинарных смесей «хлороформ - этанол» (2:1) или «дихлорметан - этанол» (2:1). Процедура была следующей: биомассу заливали смесью растворите- 
лей, нагревали на водяной бане с обратным холодильником до температуры кипения (68$\left.70{ }^{\circ} \mathrm{C}\right)$. Процедуру повторяли три раза, время экстракции составило 6 часов. Далее после отстаивания экстракт концентрировали и ПЗГБ осаждали двойным объёмом гексана.

Для исследования эффективности безреагентного метода экстракции биомассу бактерий обрабатывали детергентом додецилсульфатом натрия (ДДС-Na) различной концентрации (1-5 \%) при температуре от 25 до $110^{\circ} \mathrm{C}$.

Показателями эффективности экстракции выступали: расход реагентов, полнота извлечения полимера, степень его химической чистоты и молекулярно-массовые характеристики. Полнота извлечения определялась как процент от исходного содержания полимера в биомассе. Начальное и конечное содержание полимера в биомассе определялось с использованием хроматографа с хромато-массдетектором (6890/5975C, Agilent Technologies, U.S) (Braunegg et al., 1978).

Молекулярно-массовые характеристики определяли с использованием жидкостного хроматографа (Agilent Technologies 1260 Infinity, U.S).

Остаточные липиды, включая жирные кислоты (ЖК) как показатель загрязнения полимера, определяли с использованием хроматографа с хромато-масс-детектором (6890/5975C, Agilent TechnologiesU.S) (Калачева и др., 2007). Белки определялись методом Кьельдаля (Allen, 1935).

Математическую обработку экспериментальных данных проводили стандартными методами; определяли средние значения результатов; рассчитывали отклонения от среднего значения для каждого результата; дисперсию, стандартное отклонение отдельного результата и стандартное отклонение среднего результата. Проверку надежности полученных результатов выявляли по критерию Стьюдента при избранной доверительной вероятности $\alpha=0.95$. Полученные результаты проверяли по одному из вышеописанных способов (по критериям максимального отклонения Стьюдента) на наличие грубых ошибок. После исключения грубых ошибок производили повторную обработку результатов. Поиск оптимальных условий процесса экстракции осуществляли методами полного факторного эксперимента и крутого восхождения по поверхности отклика. Для решения поставленных задач использовалась программа MS Offis Exel 2007 с встроенным пакетом анализа данных (Ашмарин и др., 1971).

\section{Результаты и обсуждение}

Экстракция ПГА

с применением растворителей

При исследовании растворимости ПГА обнаружено, что самая высокая растворимость достигается при использовании тетрахлорэтана (табл. 1). Однако его применение нежелательно вследствие высокой токсичности (сильный почечный и печеночный яд); предельно допустимая концентрация паров в воздухе 0,001 мг/м³ (Ошина, 1978). На процесс растворения также оказывает влияние химический состава ПГА. Показано, что растворимость сополимерных образцов ПЗГБ/ПЗГВ выше, чем у гомогенного ПЗГБ.

Вязкость полимерных растворов колебалась в очень широких пределах: 1-1000 Пасс в зависимости от концентрации раствора и температуры среды. Зависимость вязкости от температуры носила характер, типичный для термопластичных полимеров: вязкость быстро падала с ростом температуры. Растворы изученных полимеров в дихлорэтане, тетрахлорэтане и диоксане склонны к гелеобразованию при охлаждении. Гелеобразование 
Таблица 1. Максимальная растворимость образцов ПГА (весовая доля, \%)

\begin{tabular}{|l|c|c|c|c|c|}
\hline \multirow{2}{*}{$\begin{array}{c}\text { Образец } \\
\text { ПГА }\end{array}$} & \multicolumn{5}{|c|}{ Растворитель } \\
\cline { 2 - 6 } & Хлороформ & Дихлорметан & Дихлорэтан & Тетрахлорэтан & Диоксан \\
\hline $\begin{array}{l}\text { ПЗГБ/ПЗГВ } \\
(10 \text { мол. \% 3ГВ) }\end{array}$ & 30 & 31 & 28 & 42 & 26 \\
\hline $\begin{array}{l}\text { ПЗГБ/ПЗГВ } \\
(23 \text { мол. \% ГВ })\end{array}$ & 24 & 24 & 26 & 44 & 22 \\
\hline ПЗГБ & 6 & 7 & 7 & 11 & 5 \\
\hline
\end{tabular}

происходит при комнатной температуре даже в относительно низко концентрированных растворах (до $10 \%$ для сополимеров ПЗГБ/ ПЗГВ и 2-3 \% - для ПЗГБ).

На примере хлороформа показано, что с увеличением объема растворителя полнота экстракции полимера возрастала практически линейно. Так, в режиме однократного извлечения полимера при использовании от 5 до 10 объемов растворителя на один объем сырой биомассы полнота экстракции составила соответственно 22 и 58 \%; с увеличением объёма растворителя полнота экстракции увеличилась до 74 \%. Молекулярная масса полученных образцов $\left(\mathrm{M}_{\mathrm{B}}\right)$ не зависела от объема использованного растворителя. Соотношение биомасса - растворитель прежде всего определяется предельной растворимостью полимера (для сополимеров возможно уменьшить это соотношение за счёт лучшей растворимости последних) и его содержанием в биомассе.

С целью повышения эффективности процесса (снижения времени и расхода растворителей) исследовано влияние нагревания и кратности экстракции на полноту извлечения полимера (ПЗГБ) из биомассы бактерий. При однократной обработке биомассы хлороформом при комнатной температуре $\left(25^{\circ} \mathrm{C}\right)$ в течение 2 ч извлечение полимера было низким - $20 \%$. Затруднения вызваны особенностями строения клеточных мембран, а также наличием воды, которая содержится в биомассе и не смешивается с выбранными растворителями. При повторном цикле полнота извлечения возросла до 49 \%; после трехкратного повторения процедуры удалось извлечь 57,4 \% полимера.

Установлено, что проведение процесса при нагревании смеси до $66{ }^{\circ} \mathrm{C}$ полнота экстракции полимера значительно увеличивается и при трехкратном извлечении возрастает до $80 \%$. Повторение процедуры не привело к значительному увеличению степени извлечения, но увеличило длительность процесса и расход растворителя, при трёхкратной экстракции расход растворителя составил 99,1 г/г ПЗГБ, при пятикратной - 115,2 г/г ПЗГБ. Замена хлороформа дихлорметаном дала аналогичные выходы полимера (порядка 80 \%) и не привела к увеличению степени извлечения.

При добавлении к хлороформу или дихлорметану этилового спирта и проведении трёхкратной экстракции с нагреванием выход ПЗГБ увеличивался максимально до $88,5-$ 89,8 \%. Этиловый спирт вытягивает воду из клетки и способствует разрушению бислойной структуры клеточной мембраны, при этом происходит агрегация липидных молекул внутри мембраны, сопровождаемая появлением в мембране воды. В результате этого барьерные функции мембраны снижаются (Gurtovenko et al., 2009), поэтому экстракция 
Таблица 2. Характеристики образцов ПЗГБ, выделенных из биомассы с применением различных реагентов

\begin{tabular}{|c|c|c|c|c|c|c|}
\hline Номер & Способ экстракции ПГА & $\begin{array}{c}\text { Время } \\
\text { эктсракции, } \\
\text { ч }\end{array}$ & $\begin{array}{c}\text { Полнота } \\
\text { экстракции, \% }\end{array}$ & $\begin{array}{l}\mathrm{M}_{\mathrm{B}} 10^{5} \\
\text { Г/моль }\end{array}$ & $\begin{array}{c}\text { Липиды, \% } \\
\text { от массы } \\
\text { образца }\end{array}$ & $\begin{array}{c}\text { Сумма } \\
\text { жирных } \\
\text { кислот мол, \% }\end{array}$ \\
\hline 1 & $\begin{array}{l}\text { Хлороформ : этанол (2:1 } \\
\text { по объему) }\end{array}$ & 6 & 88,5 & 6,2 & 3,0 & 2,4 \\
\hline 2 & $\begin{array}{l}\text { Дихлорметан : этанол (2:1 } \\
\text { по объему) }\end{array}$ & 6 & 83,2 & 6,4 & 2,8 & 2,2 \\
\hline 3 & $\begin{array}{l}\text { Хлороформ:этанол (2:1 по } \\
\text { объему), нагревание }\end{array}$ & 6 & 91,0 & 5,5 & 1,8 & 1,3 \\
\hline 4 & $\begin{array}{l}\text { Дихлорметан : этанол (2:1 } \\
\text { по объему), нагревание }\end{array}$ & 6 & 92,3 & 5,8 & 2,0 & 1,4 \\
\hline 5 & $\begin{array}{l}\text { Предварительная } \\
\text { обработка этанолом } \\
\text { при рН 10-11, } \\
\text { обработка ацетоном, } \\
\text { перерастворение гранул } \\
\text { в хлороформе }\end{array}$ & 8 & 94,8 & 3,4 & - & - \\
\hline
\end{tabular}

клеточного содержимого, в данном случае полимера, облегчается.

Помимо типа растворителя варьировали температуру экстракции. Получена серия образцов, которые различались как по величине молекулярной массы, так и степени химической чистоты (табл. 2). Так, образец № 1 получен экстракцией полимера из биомассы смесью (хлороформ-спирт 2:1 по объему). В образце присутствовали остаточные липиды до 3 \%. Образец № 2 получен аналогично, при использовании дихлорметана выход полимера составил 83,2 \%, содержание липидов $-2,8 \%$. Применение нагревания повышало полноту экстракции. Образцы № 3 и 4 экстрагировали при нагревании до температуры кипения смесей в течение часа, затем осаждали ПГА двойным объёмом гексана и отделяли осажденный полимер фильтрованием. Содержание липидов в образцах составило около двух процентов, полнота извлечения возросла до 91 \%. Образец № 5 получен модифицированным методом с использованием дихлорметана, включающим предваритель- ную обработку биомассы этиловым спиртом при рН 10.5-11.0 и кипячением с обратным холодильником в течение 30 мин с двукратной отмывкой полимера этанолом, последующей обработкой биомассы ацетоном, центрифугированием и экстракцией обезжиренной биомассы дихлорметаном. Такая обработка позволила получить образец, свободный от липидных загрязнений.

В молекулярно-массовом распределении выделенных образцов ПГА отмечена тенденция снижения $\mathrm{M}_{\mathrm{B}}$ по фракциям, полидисперсность образцов 1 и 2 составила 2,5-2,9. У образцов 3 и 4, как видно из табл. 2, Мв снижается по сравнению с образцами 1 и 2, однако это можно объяснить не деградацией полимера, а присутствием низкомолекулярных фракций в большем объеме, полидисперсность образцов 3 и 4 была значительно выше и лежала в пределах 3,1-3,5. Применение предварительной обработки биомассы щелочным спиртом с последующей обработкой ацетоном позволило повысить выход и чистоту полимера, однако наблюдалось значительное падение молеку- 
лярной массы полимера (от $6,2 \cdot 10^{5}$ до $3,4 \cdot 10^{5}$ г/моль). Показано, что процедура экстракции осложняется использованием трёх различных взаимно смешивающихся растворителей, в результате чего регенерация и их возврат в производство становится весьма сложной и энергозатратной операцией.

Как следует из данных табл. 2, количество примесей (липидов и ЖК) было в образцах полимера значительным и в зависимости от метода могло составлять от 1 до $3 \%$; сумма жирных кислот от 1,3 до 2,4 \%.

Учитывая, что хлороформ более токсичен, чем дихлорметан (4 и 2-й класс опасности) (Емнова и др., 1977), дихлорметан имеет большую растворяющую способность по отношению к ПЗГБ (табл. 1), не образует азеотропы с осадителем (гексан), или его азеотропа лежит в приемлемых для экстракции пределах, кроме того, стоимость дихлорметана значительно ниже, чем у хлороформа, дальнейшее применение хлороформа в качестве экстрагента для ПЗГБ является нецелесообразным.

В дальнейших опытах в качестве растворителя использовали дихлорметан. В качестве осадителя во всех опытах применяли гексан, хотя для осаждения можно использовать любой растворитель, который не является растворителем для ПЗГБ: этиловый, метиловый, изопропиловый спирт. Основная проблема заключается в образовании азеотропных смесей между некоторыми парами растворителей, что негативно сказывается на их регенерации и возврате в производство. Наиболее приемлемой принята пара «экстрагент - осадитель» смесь дихлорметана с гексаном, которая не образует азеотропной смеси (Ошина, 1978). Следует отметить, что применяемые в качестве осадителей легковоспламеняющиеся жидкости (ЛВЖ) делают необходимым организацию специальных мер безопасной работы и хранения, тем не менее применение этого метода оправдано для получения ограниченных по объемам партий полимера высокой степени чистоты, например для биомедицинских целей.

Таким образом, экстракция ПГА из биомассы клеток при модификации метода варьированием составом экстрагентов, температуры и ряда других параметров позволяет достичь 92-96 \% полноты извлечения полимера и минимизировать примеси (табл. 3). Однако при этом неизбежно возникает необходимость введения блока разделения смеси «растворитель - осадитель», что значительно усложняет процесс. Так, при использовании системы «дихлорметан - этанол» с последующим осаждением гексаном образуется азеотропная смесь гексана с этанолом. Для предотвращения образования азеотропной смеси «гексан - этанол» будет целесообразно проводить предварительно обработку биомассы этанолом, а уже на следующей стадии - экстракцию дихлорметаном. Можно предложить второй вариант: отказаться от использования в качестве осадителя гексана и проводить процесс осаждения ПЗГБ этанолом. Такая замена не оказывает негативного влияния на продукт при надлежащем качестве этилового спирта.

\section{Исследование безреагентного метода экстракиии ПГА}

Для обработки биомассы бактерий был выбран додецилсульфат натрия (ДДС-Na) один из самых распространённых и сравнительно недорогих детергентов, который в настоящее время получил широкое распространение в парфюмерной, химической, фармацевтической промышленности. Действие ДДС-Nа основано на его солюбилизирующей способности. Целью данной обработки являлось удаление липидных и белковых фрак- 


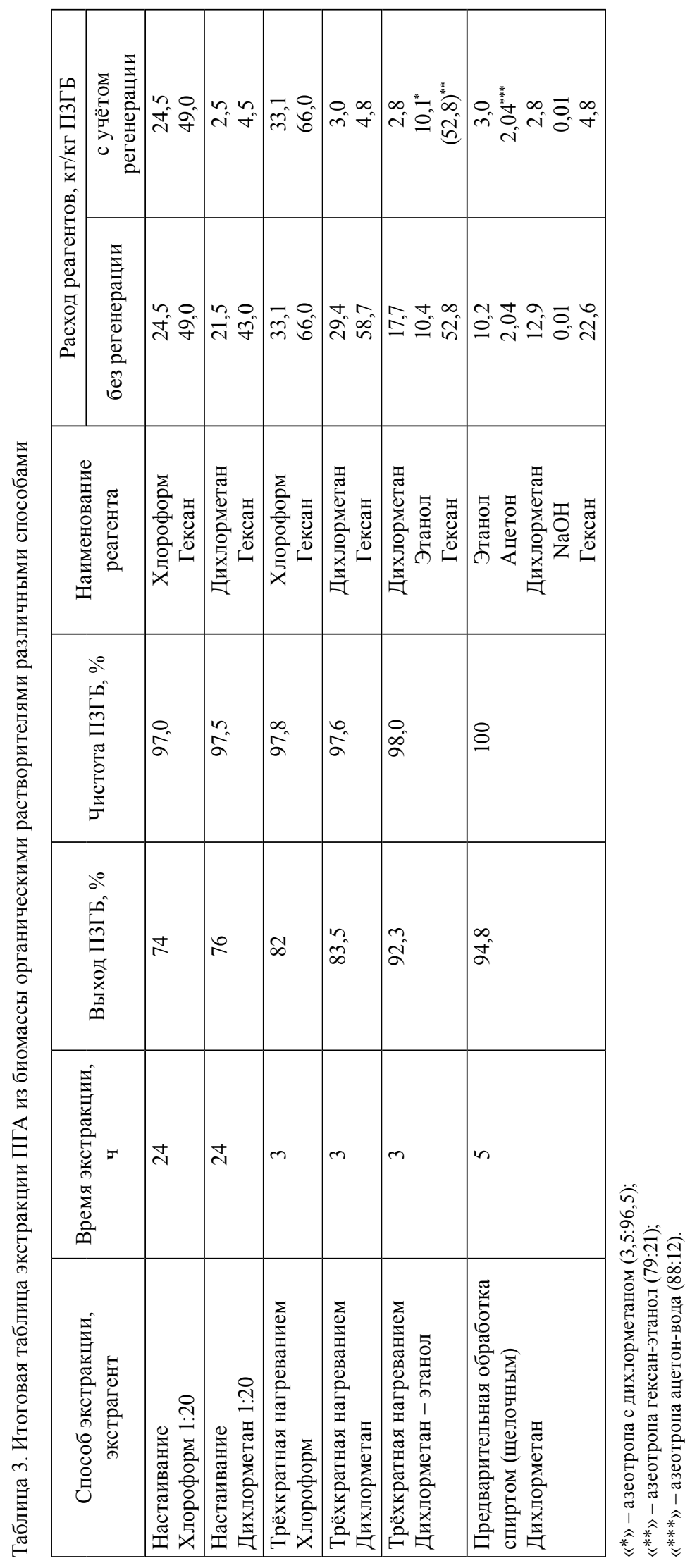


ций из биомассы и получение гранул ПзГБ. Обработку проводили в течение часа при различной температуре. Принимая во внимание, что в результате такой обработки ПЗГБ не растворяется, а в раствор переходят из биомассы липиды и вещества белковой природы, в качестве критерия оценки эффективности обработки выбрана чистота полимера. Расход ДДС-Nа в опытах в среднем составил 0,12-0,62 г/г ПЗГБ (табл. 4). Лучшие результаты достигнуты в опыте № 9. Полученные образцы имели достаточно большой разброс по примесям. Наименьшее содержание липидов в пересчёте на ЖК содержит образец № 9 (0,2-0,4 \%), полученный при обработке 5\%-ным раствором ДДС-Na. В образцах № 7 и 8 содержание жирных кислот составило порядка $0,8-1,1 \%$, кроме того, во всех образцах зафиксировано наличие 1-7 \% веществ белковой природы.

С изменением количества примесей менялась молекулярная масса образцов. Образцы, содержащие наибольшее количество примесей, характеризуются наименьшей молекулярной массой $\mathrm{M}_{\mathrm{B}}=3,4 \cdot 10^{5}-4,2 \cdot 10^{5}$ и довольно большой полидисперсностью $\mathrm{D}=7,0$ -
11. Со снижением примесей в образцах полидисперсность снижается $\mathrm{D}=2,8-3,2$, а молекулярная масса растёт $\mathrm{M}_{\mathrm{B}}=5,8-6,310^{5}$ г/ моль. Влияние температуры также имело положительный эффект на количество примесей в полимере, и с ростом температуры чистота полимера увеличивается. Лучшие показатели достигнуты при обработке при $60{ }^{\circ} \mathrm{C}$, чистота для различных концентраций составила - 87; 91; 93 \% соответственно. Кроме температуры, большое влияние на чистоту полимера оказывала длительность обработки биомассы. Обработку биомассы проводили при температуре $60{ }^{\circ} \mathrm{C}$ в течение $20,40,60,100$ мин. Показано, что с увеличением продолжительности обработки чистота полимера возрастала линейно. Наиболее высокая степень чистоты полимера получена при обработке в течение 60 мин (93\%), дальнейшая обработка не приводила к повышению чистоты образцов. В результате обработки биомассы растворами детергента удалось получить образцы полимера с чистотой $92 \%$; при этом доля липидов составила 0,2-0,4 \%. При обработке детергентами из полимера удалены практически все липидные составляющие, разру-

Таблица 4. Выход полимера ПЗГБ после обработки биомассы Cupriavidus eutrophus ДДС-Na (концентрация ПЗГБ в исходной биомассе $81,2 \%$ )

\begin{tabular}{|c|c|c|c|c|c|c|}
\hline Номер & $\begin{array}{c}\text { Концентрация } \\
\text { ДДС-Na, \% }\end{array}$ & Температура, ${ }^{\circ} \mathrm{C}$ & $\begin{array}{c}\text { Выход, \% } \\
\text { от а.с.б. }\end{array}$ & $\begin{array}{c}\text { Содержание } \\
\text { примесей, \% }\end{array}$ & $\begin{array}{c}\mathrm{M}_{\mathrm{s}} \cdot 10^{5} \\
\text { г/моль }\end{array}$ & Пд \\
\hline 1 & 1 & 20 & 96,42 & 16,65 & 3,4 & 7,1 \\
\hline 2 & 2,5 & 20 & 94,83 & 14,37 & 3,5 & 6,9 \\
\hline 3 & 5 & 20 & 93,14 & 12,92 & 3,9 & 4,2 \\
\hline 4 & 1 & 40 & 95,31 & 14,91 & 4,2 & 4,5 \\
\hline 5 & 2,5 & 40 & 92,21 & 12,94 & 4,9 & 3,8 \\
\hline 6 & 5 & 40 & 90,13 & 9,91 & 5,8 & 3,4 \\
\hline 7 & 1 & 60 & 93,11 & 12,78 & 5,1 & 2,9 \\
\hline 8 & 2,5 & 60 & 89,53 & 9,30 & 6,2 & 2,7 \\
\hline 9 & 5 & 60 & 87,38 & 7,07 & 6,3 & 2,7 \\
\hline
\end{tabular}

Примечание: содержание примесей - суммарное содержание белков, липидов и других неидентифицированных компонентов в полученном образце полимера. 
шены клеточные стенки, предположительно при последующей обработке органическими растворителями удастся снизить расходы на растворители. Такая обработка позволяет на втором этапе не использовать смеси растворителей (трихлорметан - этанол), а применять чистые компоненты, что исключает образование азеотропных смесей, снижает расходы на регенерацию растворителей.

\section{Разработка комбинированного метода экстракичии ПГА}

С целью повышения полноты извлечения полимера и снижения количества примесей в нем исследован комбинированный метод. Сущность метода заключается в том, что биомассу предварительно обрабатывали 5\%-ным раствором ДДС-Na в течение одного часа при $60{ }^{\circ} \mathrm{C}$, затем биомассу центрифугировали и отмывали водой. Далее проводили очистку дихлорметаном с последующим осаждением полимера гексаном. Для этого полимер, полученный на первой стадии, трёхкратно экстрагировали равными порциям дихлорметана в соотношении 1:10 при нагревании (табл. 5).

Полученные образцы характеризовались высокой степенью чистоты, примеси отсутствовали. Степень извлечения ПЗГБ составила 98-99 \%, молекулярно-массовое распределение сохраняло тенденцию, описан- ную выше и, как выясняется, характерную для всех образцов ПЗГБ выделенных много-

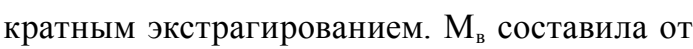
$6,2 \cdot 10^{5}-6,8 \cdot 10^{5}$ г/моль, коэффициент полидисперсности для образцов лежал в пределах 2,9-3,2. Наибольшая концентрация полимера приходится на первый акт экстракции - 56,28 г/л, следующие экстракты сильно разбавлены, второй акт - 17,4 г/л, третий акт $-6,02$ г/л.

С целью сокращения расхода растворителей при первом акте экстракции соотношение полимер - дихлорметан составило 1:10, а далее 1:5. Сокращение расхода дихлорметана не повлияло на степень извлечения полимеpa $-98,9 \%$.

В результате обработки биомассы комбинированным методом удалось повысить степень извлечения полимера до 98,5 \%. Чистота выделенного полимера во всех вариантах превысила 99,5. Используя на первой стадии обработку биомассы детергентом, удалось сократить расход растворителей на второй стадии очистки полимера.

Учитывая сложность и многофакторность процесса экстракции ПГА из биомассы бактерий, выполнена оптимизация технологии, основанная на регрессионном анализе многофакторного эксперимента. Используя метод крутого восхождения по поверхности отклика, найдены оптималь-

Таблица 5. Экстракция биомассы комбинированным методом

\begin{tabular}{|l|l|c|c|c|c|}
\hline $\begin{array}{c}\text { П-ЗГБ после } \\
1 \text { стадии, \% }\end{array}$ & \multicolumn{1}{|c|}{ Реагенты } & Выход ПЗГБ, \% & $\begin{array}{c}\text { Чистота } \\
\text { ПЗГБ, \% }\end{array}$ & $\begin{array}{c}\text { Расход } \\
\text { реагентов, } \\
\text { кг/кг ПЗГБ }\end{array}$ & $\begin{array}{c}\text { Степень } \\
\text { регенерации, } \\
\%\end{array}$ \\
\hline 90,81 & Дихлорметан & 98,11 & 99,9 & 16,81 & 90 \\
& Этанол & & & 9,90 & 0 \\
& Гексан & & & 24,65 & 0 \\
\hline ДДС-Na & & & 0,62 & 90 \\
& Дихлорметан & 98,99 & 99,9 & 25,22 & 90 \\
\hline
\end{tabular}


ные параметры процесса: концентрация ДДC-Na - $5 \%$; температура $60{ }^{\circ} \mathrm{C}$; время обработки 40 минут.

Анализ молекулярно-массового распределения показал, что ПЗГБ, выделенный из биомассы, имеет очень большую полидисперсность - от 2,8 до 3,5 и $\mathrm{M}_{\mathrm{w}}$ от $6,5 \cdot 10^{5}$ до $7,0 \cdot 10^{5}$ г/моль. Использование многократной экстракции позволяет осуществить разделение ПЗГБ на более узкие фракции по молекулярной массе. Такое фракционирование может быть полезно в процессе изготовления различных изделий. Так, низкомолекулярные фракции могут использоваться для создания наноструктур, а высокомолекулярные - в производстве тканых материалов и изделий, получаемых методами литья из расплавов или растворов.

\section{Заключение}

В результате выполненного сравнительного исследования различных методов экстракции ПГА из биомассы бактерий предложено два подхода: с применением экстрагента (дихлорметан) и осадителя (гексан) для получения образцов биомедицинского назначения и безреагентный метод с применением детергента додецилсульфата натрия (ДДС-Na), позволяющего более экономичным способом получать высокие выходы полимера для технических целей. Применение разработанного комбинированного метода позволяет сократить объём органических растворителей, используемых в процессе, и снизить их расход до 4,4 кг/кг ПГА при полноте экстракции до 98,5-99,0 \% и высокой степени чистоты полимера, пригодного для медицины.

\section{Список литературы}

1. Ашмарин И.П., Васильев Н.Н., Амбросов В.А. (1971) Быстрые методы статистической обработки и планирования экспериментов. Л.: Изд-во Ленинградского университета, 80 с.

2. Емнова Е.Е., Романова А.К. (1977) Гидрогеназная активность термофильной водородокисляющей бактерии Pseudomonas thermophila. Микробиология 46: 619-623.

3. Калачева Г.С., Волова Т.Г. (2007) Состав жирных кислот липидов Wautersia eutropha в условиях активного синтеза полигидроксиалканоатов. Микробиология 76: 1-7.

4. Ошина Л.А. (1978) Промышленные хлорорганические продукты: справочник. - М.: Химия. $-656 \mathrm{c}$.

5. Allen W.F. (1931) A micro-Kjeldahl method for nitrogen determination. Journal of the American Oil Chemists Society 8: 391-397.

6. Blauhut W., Gierlinger W., Strempfl F. (1993) US Patent 5213976.

7. Braunegg G., Sonnleitner B., Lafferty R.M. (1978) A rapid gas chromatographic method for the determination of poly-b-hydroxybutyric acid in microbial biomass. Eur. J. Appl. Microbiol. 6: $29-37$.

8. Breitenbach A., Mohr D., Kissel T. (2000) Biodegradable semi-crystalline comb polyesters influence the microsphere production by means of a supercritical fluid extraction technique (ASES). J. Control. Rel. 63: 53-68.

9. Choi J., Lee S.Y. (1997) Process analysis and economic evaluation for poly(3-hydroxybutyrate) production by fermentation. Bioprocess Eng. 17: 335-342.

10. Choi J., Lee S.Y. (1999a) Efficient and economical recovery of poly-(3-hydroxybutyrate) from recombinant Escherichia coli by simple digestion with chemicals. Biotechnol. Bioeng. 62: 546553. 
11. Choi J., Lee S.Y. (1999b) Factors affecting the economics of polyhydroxyalkanoate production by bacterial fermentation. Appl. Microbiol. Biotechnol. 51: 13-21.

12. Devdatt L. Kurdikar F., Strauser E., Solodar A. J., Mark D.P. (2000) US Patent 6087471.

13. Gurtovenko A.A., Anwar J. (2009) Interaction of ethanol with biological membranes: The formation of non-bilayer structures within the membrane interior and their significance. J. Phys. Chem. B. 113: 1983-1992.

14. Hahn S.K., Chang Y.K., Kim B.S. et al. (1994) Optimization of microbial poly(3-hydroxybutyrate) recovery using dispersion of sodium hypochlorite solution and chloroform. Biotechnol. Bioeng. 44: $256-261$.

15. Horowitz D. (2002) US Patent 6340580.

16. Jian Yu (2009) US Patent 7514525.

17. Page W.J., Comnish A. (1993) Growth of Azotobacter vinelandii UWD in fish peptone medium and simplified extraction of poly- $\beta$-hydroxybutyrate. Appl Environ Microbiol. 59: 4236-4244.

18. Ramsay J.A., Berger E., Voyer R., Chavarie C., Ramsay B.A. (1994) Extraction of poly-3hydroxybutyrate using chlorinated solvents. Biotechnol. Tech. 8: 589-594.

19. Rodrigues M.F.A., Silva L.F., Gomez J.G.C., Valentin H.E., Steibüchel A. (1995) Byosinthesis of poly(3-hydroxybutyric acid-co-3-hydroxypentoic acid) from unrelated substances by Burkholderia sp. Appl Microbiol Biotechnol. 43: 880-886.

20. Steinbüchel A., Aerts K., Babel W., Föllner C., Liebergesell M., Madkour M.H., Mayer F., PieperFürst V., Pries A., Valentin H.E., Wieczorek R. (1995). Considerations on the structure and biochemistry of bacterial polyhydroxyalkanoic acids inclusions. Can. J. Microbiol. 41: 94-105.

21. Tamer L.M., Moo-Young M., Chisti Y. (1998) Optimization of poly(3-hydroxybutyric acid) recovery from Alcaligenes latus: combined mechanical and chemical treatments. Bioprocess Enginner. 19: 459-468.

22. Thakor N., Lütke-Eversloh T., Steinbüchel A. (2005) Application of the BPEC pathway for large scale biotechnological production of poly(3-mercaptopropionate) by recombinant Escherichia coli including a novel in situ isolation method. Appl. Environ. Microbiol. 71: 835-841.

23. Yang Y., Chung T. (2001) Morphology, drug distributution, and in vitro release profiles of biodegradable polymeric microspheres containing protein fabricated by double-emulsion solvent extraction/evaporation method. Biomaterials 22: 231-241.

24. Yang Y.H., Brigham C., Willis L., Rha C., Sinskey A. (2011) Improved detergent-based recovery of polihydroxyalkanoates (PHAs). Biotechnol Lett. 33: 937-942. 